The final version of this paper was published in International Journal of Production Economics Vol. 131, No. 1, pp. 30-43 (2011)

http://dx.doi.org/10.1016/j.ijpe.2010.12.022 


\title{
Factors Influencing Employee Perceptions in Lean Transformations
}

\author{
Dávid Losonci ${ }^{1}$, Krisztina Demeter ${ }^{2}$ and István Jenei ${ }^{3}$ \\ Dept of Logistics and Supply Chain Management, Corvinus University of Budapest, \\ Fővám tér 8, Budapest, H-1093, Hungary \\ 1 david.losonci@uni-corvinus.hu \\ ${ }^{2}$ krisztina.demeter@uni-corvinus.hu \\ ${ }^{3}$ istvan.jenei@uni-corvinus.hu
}

\begin{abstract}
The purpose of the study was to investigate employee perceptions during a lean transformation ${ }^{1}$. The combination of case study and survey methodologies was used to define elements influencing the perceived lean success of shop floor employees. According to our findings, belief, commitment, work method and communication all have a considerable direct impact on workers' perceptions of lean success. However, their effects are very different based on the scope and focus of changes that is influenced by process characteristics. Perceptions regarding successful lean transformation during a moderate reorganisation of the company's welding plant, where mainly males work, are affected only by commitment and work method, whereas the deep reorganisation of the sewing plant (populated by female employees) is only influenced by belief and communication.
\end{abstract}

Keywords: lean transformation; worker perceptions; gender; work environment

\footnotetext{
${ }^{1}$ The contribution of the authors is $60 \% / 35 \% / 5 \%$, respectively.
} 


\section{Introduction}

The fierce competition in the automotive industry forces companies at all levels of the supply chain to seek more effective operations. Recent decades have proven with certainty that the best "path" to pursue is Toyota's lean strategy. Lean production, first described in detail by Womack, Jones and Roos (1990) in their revolutionary book, "The Machine that Changed the World", has its roots in the Toyota Production System (TPS) (Ohno, 1988). Today, lean manufacturing is a complex system that extends throughout a company and beyond its borders (Hines et al., 2004; Matsui, 2007; Warnecke and Hüser, 1995; Womack and Jones, 2003). Lean production is standard in the global automotive industry and is gaining ground in other manufacturing sectors (Abdulmalek and Rajgopal, 2007; Panizzolo, 1998) and even service industries (Womack and Jones, 2003).

Achieving lean production is a long and practically constant process during which the participants must continuously manage (Karlsson and Ahlström, 1996) and undergo changes. Its implementation is accompanied by radical changes from the beginning. These changes have a remarkable impact on performance (e.g., lead time, quality) and also substantially affect stakeholders (e.g., managers, workers) (Womack et al., 1990). Assessments of the success of change processes (i.e., lean implementation) are usually restricted to measuring operational and financial performance. What employees actually perceive, think and feel about lean implementation, the human aspect, has received less attention.

In this paper, we explore 'soft' building blocks (e.g., commitment, belief) of successful lean implementation on the shop floor level. To determine how things happen in real company settings and to provide a genuine explanation of contingency factors, decisions and behaviors, we used a combined methodology including a case study and a survey at a Hungarian-owned automotive parts supplier. Our objective is to determine which factors make workers feel that lean transformation was successful in order to reveal the building blocks of successful lean transformations.

The remainder of the paper is organised as follows. In section 2, we present our review of the literature on lean and similar organisational transformation processes, focusing on the major inner stakeholders. In sections 3 and 4, the case company is introduced, and the research methodology is explained. In section 5, we operationalise our model, and in section 6 , we analyse the empirical data. The paper closes with some discussion, limitations and conclusions.

\section{Literature review}

Most of the radical organisational and cultural turnarounds fail or show limited positive progress (Kotter, 1995). Lean transformation experiences work in accordance with Kotter's conclusions. Despite the large number of firms in a variety of industries attempting to pursue lean production, only a few achieve the expected results (Bhasin and Burcher, 2006; Koenigsaecker, 2005; LEI, 2004). One key reason is the use of the 'set of practices' approach to lean manufacturing (Browning and Heath, 2009) rather than the integrated socio-technical system view (Macduffie, 1995; Shah and Ward, 2007). Today, the evolving lean concept highlights the underlying philosophy, including the human factor and its role in the implementation and "perfection" phases (Hines et al., 2004; Koenigsaecker, 2005).

Awareness regarding the importance of managing employees during lean conversion is not new, as the following sentence from 1991 reveals: "We know very little about the causes of implementation problems, but the evidence seems to suggest that human resource issues often are their root" (Huber and Brown, 1991, p.156). However, the vast majority of the empirical work does not focus on the transition process itself, especially not from workers' perspective. Researchers have instead enriched "general" knowledge in this topic, including the use of 
human resource practices in a lean environment (Forza, 1996; Macduffie, 1995), the performance effects of human resources management practices in advanced production settings (Ahmad et al., 2003; Birdi et al., 2008; Patterson et al., 2003), and studies of issues such as critical success factors in kaizen (Farris et al., 2009) or in cellular manufacturing (Hyer et al., 1999).

There are several studies (and many anecdotal stories) about successful lean transformations (Yauch and Steudel, 2002; Vernables, 2005). All of them emphasise soft issues and overlap with Kotter's (1995) seminal work. However, the number of publications investigating lean implementation (or similar initiatives like cellular manufacturing) on the shop floor level is very limited (Olorunniwo and Udo, 2002; Yauch and Steudel, 2002). Even fewer studies consider workers' feelings and perceptions (Brown and Mitchell, 1992; Shafer et al., 1995), and none of them considers employees' feeling of success, which we think are crucial to successful lean implementation.

If we seek to identify the factors influencing employees' perceptions of successful lean transitions, we must understand the new shop floor work environment and how lean manufacturing changes workers' everyday lives (2.1). Then we review the external (2.2) and internal (2.3.) factors that most likely shape worker's perceptions during the conversion process. We argue that external factors are linked to the change process and to changes in structural and infrastructural work environments and refer to the internal factors as intrinsic components. Finally, we consider important contextual elements (2.4).

\subsection{Lean production at the shop floor level}

What really changes at the shop floor level with lean manufacturing? People must be able to perform multiple tasks on the production line to provide flexibility for the plant and ensure a balanced load for everyone. They may have to handle more than one machine simultaneously, and they are frequently rotated among work-stations. In addition to being asked to multitask, workers usually also become responsible for basic maintenance activities, including tidying up and cleaning their workplace (5S). These latter activities are already part of heavy standardisation, a key feature of lean management (Spear and Bowen, 1999). Standardisation reduces work autonomy, can increase monotony, and according to some authors, leads to unlimited performance demands and stressful work. These are typical arguments against lean production (Berggren, 1993; Landsbergis et al., 1999; Skorstad, 1994; Mehri, 2006). Work methods and worker motions are usually very rigid and routine-based, which in itself can lead to a lower need for professional skills and thus reduce the level of satisfaction among workers (Newsome, 2003).

However, there is another level of change involved in lean production: workers have more freedom in dividing their work within their group, and they become responsible for the level of quality that they provide, for improvements in that regard, and for other work-related issues. This higher-level individual and group responsibility is supported by faster and more understandable information feedback, and people are trained on how to cope with problems and manage their group activities. This second group of changes, which rely on people as thinking humans instead of considering them as only "two hands", can develop intrinsic motivation and commitment in workers (de Treville and Antonakis, 2006). Womack et al. also write that lean production "...provides more challenging and fulfilling work for employees at every level, from factory to the headquarters" (Womack et. al., 1990, p. 225).

\subsection{External factors shaping perceptions at the shop floor level}

We consider the organisational climate (Shadur et al., 1999) that is the factors, impacts, impressions that shape employee perceptions as external. These influences will form the basis 
of internal, intrinsic values that leads employee feelings, attitudes and reactions. We divide our discussion into these two parts.

As we mentioned earlier, lean manufacturing has a considerable effect on blue-collar labour. One of the most obvious changes is the introduction of a wide range of new principles and methods that radically reshape operations (tasks, roles) at the shop floor level. The new working methods necessarily affect worker perceptions. Because employees are usually concerned with their own tasks and "direct" work environment (e.g., materials handling, linked operations in the cell, the shop level), perceptions regarding the success or failure of lean manufacturing from workers' point of view can be derived largely via employees' own experience. However, these perceptions can also be highly changed by communication.

Kotter (1995) regards communication as a key element of successful organisational renewal. In his organisation transformation model, leaders should use every vehicle possible to communicate, e.g., vision, strategy, and results. Udo and Ehie (1996) identify 18 determinants of critical success for advanced manufacturing technology $\left(\mathrm{AMT}^{2}\right)$ implementations. Among others, communication affects the expected tangible and intangible benefits of the conversion significantly and positively. Tracey and Flinchbaugh (2006) also underline the significance of organisational communication in lean conversion, as did Linstead et al. (2005) when they concluded that to get the best out of the staff, managers needed to communicate with rather than dictate to their subordinates.

Thus, the method and content of work and communication must be considered when we look for determinants of worker perceptions.

\subsection{Internal factors shaping perceptions at the shop floor level}

Before any radical changes occur, the management should also secure the commitment of employees through positive belief and trust in the change process.

Mowday et al. (1982) define commitment as "the relative strength of an individual's identification with and involvement in a particular organisation" (cited in Nijhof et al., 1998, p. 243; Lee and Gao, 2005, p. 377). The authors regard organisational characteristics as the most influential factor in developing commitment and highlight the weight of decentralisation and participation in decision-making (Nijhof et al., 1998). Iverson (1996) studies employee acceptance of organisational change and suggests that commitment should be considered as a main determinant, and a mediator of factors in the process. Shadur et al. (1995) study predictors of employee approval of lean production and find that commitment to the company is one important element. Total quality management (TQM) programs also show that "the commitment of employees to the goals of the organisation is a critical component of any total quality program" (Jackson, 2004, p. 714). Zairi (2002) reinforces these findings and argues that employee commitment serves as the basis for sustainable TQM systems.

Beyond commitment, belief can considerably affect perceptions regarding change. Armenakis et al. (2007) suggest that recipients' beliefs (e.g., in the need for change, in the appropriate corrective action, in the change agent etc.) influence the success of organisational change initiatives. They suggest that "belief is an opinion or a conviction about the truth of something that may not be readily obvious or subject to systematic verification" (Armenakis et al., 2007 p. 438). Vasilash (2000) adds that greater improvements are feasible if more people believe in the philosophy. Additionally, as Udo and Ehie (1996) note, if one's employees have a great deal of faith in change and perceive it to be in their best interest, many of the potential benefits can easily be realised.

According to the literature, there are relevant links among the external and internal factors through which the former facilitate the latter. For example, de Treville and Antonakis (2006)

\footnotetext{
${ }^{2}$ AMT includes manufacturing and information technologies, just-in-time (JIT), cellular manufacturing and computer-aided design and manufacturing, automated storage and so on.
} 
find that work methods can strengthen worker identification and involvement, particularly commitment. $\mathrm{Ng}$ et al. (2006) study management communication and conclude that organisation-related information distributed to employees about changes in organisational policies, procedures, employee and group success, and other similar matters is positively related to organisational commitment. Deming (1986) also emphasises the importance of organisational communication, suggesting that "when employees are knowledgeable about workplace processes that concern them and they are involved in the decision-making process relevant to their work, then both the organisation and the individual benefit" (Quinn, 2001, p. $38)$.

\subsection{Contextual factors of the change process at shop floor level}

As we can see, workers' perceptions regarding transformational success depend highly on their commitment and beliefs, and the proper communication and changes to work environments are each fundamental. However, one should also take further social and contextual factors into consideration. In the following paragraphs we highlight the most important factors. We emphasize the findings of gender-related studies because of the sharp segregation of genders in the company (mainly men in welding and mainly women in sewing, see Section 4 and Table 2).

Gender can have a significant impact on the change process. Gender segregation and stereotypical gender coding of workplaces takes place in many companies resulting in typical male and female jobs. At the point of recruitment it is already decided what gender and what gender values the company is looking for (Acker and Van Houten, 1974). In these so called gendered organisations the usually "unskilled", labour intense production areas, where new production methods (e.g., lean production, TQM, just-in-time) can bring the most advantages, are dominated mostly by female workers who are thus disproportionately affected by changes (Newsome, 2004). Taylor (2006) draws a similar conclusion and emphasises the importance of work environment. He explains work intensification and flexibility as a result of women's subordinated position within the labour process, not Japanese management techniques (e.g., lean tools). Gender hierarchy is also typical in gendered organisations: leaders are almost exclusively males and females are less able to prevent greater control than males (partly because of the paternalistic nature of their relationship with male leaders (Acker, 1990), and partly because it is more difficult for them to find another job due to their lower skills), which leads to much more rigid processes and control in their case, whereas males enjoy more freedom. Abrahamsson (2001), focusing on strategic organisational changes (e.g., TQM, business process re-engineering), finds: if gender segregation is embedded in organisations, then attempts to create gender-mixed working groups or to put outstanding women in leading positions fail. The lack of well functioning working groups, one of the most important lean tools, is strong restoring mechanism and obstacle to organisational change. Gender can also affect commitment. According to Singh et al. (2004), professional women are more committed to their organisation than are men. Other women, however, are "grateful slaves" (Hakim, 1991): they are highly satisfied with poor jobs, since for them the paid job is only secondary. While their strategy support organisational changes without too much resistance, their involvement into changes is also more difficult.

Recent studies in feminist research go even further and argue that organisational culture and norms can significantly affect how people of different genders behave. Being female or male does not necessarily create feminine or masculine behaviour (Ely and Padavic, 2007).

Shadur et al. (1995) state that the speed of work and, in special circumstances, age can influence the acceptance of lean initiatives. Higher work speed in lean systems and younger age leads to higher acceptance of lean. Finally, as TQM examples have shown, the system can be influenced by differences in national and organisational contexts (Dawson, 1994). 
"Japanisation" is more difficult in a national culture that is very far from the Japanese values, but still in this case a Japanese organisational context (e.g., in case of a Japanese subsidiary) can help. Implementation of TQM in other contexts is particularly problematic, and the competitive results are usually weak.

A summary of the relevant literature reveals the following contextual factors: process/work method characteristics, gender, and national/organisational context. The authors also suggest that process/work characteristics can affect gender coding of workplaces: women more likely, but not exclusively, are employed in "unskilled" and subordinated positions.

\section{Research methodology}

The existing literature contains the critical steps in a successful lean transformation (Hines and Taylor, 2000; Womack and Jones, 2003). Others offer an evaluation that is usually based on objective metrics and top management opinions. We go beyond the existing knowledge and establish a framework for assessing lean success at the shop floor level. Our objective in this paper is to demonstrate which factors make workers feel that a lean transformation was successful so that we can better understand the building blocks of successful lean transformations.

To explore the research problem, we used a combined methodology (Table 1). We began with the qualitative methodology (McCutcheon and Meredith, 1993). We used a "quasi"exploratory case study because our main aim was to gain support and an explanation for our survey-based study. Field research was the most appropriate method for learning about the company's general "lean history", the nature of its lean transformation and its internal/external dynamics. The number of potential cases was very limited because we were interested in studying successful conversion and its short-term effects on Hungarian mid-sized businesses. We had two contacts among mid-sized manufacturers and chose the "extremely" successful business "where the process of interest is transparently observable" (Eisenhardt, 1989, p. 537) We conducted 10 semi-structured interviews with managers, including the $\mathrm{CEO}$, the production manager, a job shop manager, a shift manager, the HR manager, the logistics manager, the financial manager, the quality manager, the head of engineering, and the lean manager. These interviews lasted between thirty minutes and two hours each. Our central questions were formulated around the lean transformation process (initiating factors, steps, acceptance, problems and solutions, each individual's role in the process, and tools) and addressed the development of human and organisational capabilities. In the second phase, to collect a sufficient amount of data about workers' perceptions and the influencing factors, we conducted a survey. 
Table 1

The steps used in the combined methodologies

\begin{tabular}{|c|c|c|}
\hline Phases & Qualitative phase: case study & Quantitative phase: survey \\
\hline $\begin{array}{l}\text { Content of the } \\
\text { phase }\end{array}$ & $\begin{array}{l}10 \text { semi-structured interviews, } \\
\text { with: } \\
\text { • CEO } \\
\text { - production manager } \\
\text { - a job shop manager } \\
\text { - a shif manager } \\
\text { - HR manager } \\
\text { - logistics manager } \\
\text { - financial manager } \\
\text { - quality manager } \\
\text { - head of engineering } \\
\text { - lean manager }\end{array}$ & $\begin{array}{l}\text { Adapting a previous } \\
\text { survey (Tracey, 2004) } \\
\text { west of questionnaire } \\
\text { with CEO and workers } \\
\quad \text { Questionnaire: } \\
\bullet \text { welding, } \mathrm{N}=22 \\
\bullet \text { rewing, } \mathrm{N}=61\end{array}$ \\
\hline Main objective & $\begin{array}{l}\text { To undestand company's } \\
\text { situation and the nature and } \\
\text { effects of lean transformation }\end{array}$ & $\begin{array}{l}\text { To collect factors influencing } \\
\text { workers' perception of successful } \\
\text { lean implementation }\end{array}$ \\
\hline
\end{tabular}

To determine the factors influencing perceptions, we used a questionnaire for workers (see Table 3 for variables) adapted from a similar previous survey (Tracey, 2004). We pilot-tested the questionnaire with two workers, one female from sewing and one male from the welding plant. The CEO also reviewed the questions before the launch. The lean manager and one of our interns helped to supervise the completion of the questionnaire. The whole process took 20-25 minutes: the lean manager asked the workers to stop their work (10-12 people each time) and go to the cafeteria to fill out the questionnaire.

Two job shops at the company were examined: welding and sewing. We received 22 questionnaires from the welding plant ( 2 of them from females) and 61 questionnaires from the sewing plant (all from females). In total, 134 people work in the two job shops per shift, which means that we achieved a response rate of $62 \%$. This ratio is high enough to adequately represent the total population. The disproportionate number of responses from the sewing plant can be traced back to the differences between the production technologies involved. The machines in the welding plant need continuous human supervision.

\section{The case company}

4.1. History and start of the lean journey

The Mór site of Rába Automotive Holding, a Hungarian-owned stock exchange company, was selected for our research in 2006.

The Japanese company Suzuki, a world leader in the production of small cars, was the first large automotive investor in Hungary at the beginning of the 1990s. Due to protectionist rules, Suzuki had to purchase parts from Hungarian suppliers. Rába's Mór site had experience with seat manufacturing. It has been a seat supplier for Ikarus, a Hungarian bus producer, for decades. In its best years, Ikarus assembled 10,000+ buses per year. The changing market conditions during the 1990s (with a decline in bus orders from post-Soviet countries), the lack of automotive experience in Hungary and the strong government support for the case company helped the site to become the first-tier seat supplier for Suzuki. Confidence and predictability characterised the mutually "captive" relationship of this firm and the Japanese manufacturer almost until 2000. At that time, Rába's Mór lost its position because the site 
could not cope with changing business conditions (e.g., the introduction of new car models, increased production volume, and new competitors in the region (Demeter et al., 2006)). The required radical reorganisation of the production system (including technology, structure, and operations) was not successfully implemented over the years, and this led to decreasing sales, lost tender, and lay-offs. Because Suzuki was the main partner of Rába's Mór site, the missed opportunities affected its financial position substantially. The site made some feeble reorganisation efforts that failed because of the lack of management commitment and expertise. Suzuki's increasing volume kept some problems hidden, but it became evident that the site was losing its opportunity to remain a first-tier supplier.

In 2005, a new CEO was appointed at Mór. He immediately began the transformation process, addressing the two most important areas of the business unit. The welding and sewing units produce finished goods for Suzuki. The two job shops gave almost half of the workforce, half of the man-hours (see Table 2) and more than the half of the revenue. In this study, we focus on these two job shops. The new CEO had comprehensive lean expertise, had led several lean transformation projects in the past and managed different lean companies. After a short training program for managers, they began with a three-month-long pilot project and built up a sewing cell, and in parallel executed two other projects in the welding shop. 18 months later, having completed 25 projects, they had a three-week-long standardised lean implementation process.

The new CEO has completely changed the autocratic leadership style. Previously the voice of the manufacturing engineer was the only one listened to in the job shops when technical changes took place. During the lean projects workers have made decisions and managers continuously ask their opinion about further improvement ideas in day-to-day discussions. The CEO himself walks around in the shop floor at least twice a week.

Table 2

Number of employees at Rába's Mór site

\begin{tabular}{|c|c|c|c|c|c|c|c|c|c|}
\hline & \multicolumn{3}{|c|}{ Rába's Mór site } & \multicolumn{3}{|c|}{ Welding } & \multicolumn{3}{|c|}{ Sewing } \\
\hline Year & Total & Male & Female & Total & Male & Female & Total & Male & Female \\
\hline 2004 & 635 & 349 & 286 & 100 & 79 & 21 & 102 & 5 & 97 \\
\hline 2005 & 583 & 321 & 262 & 91 & 75 & 16 & 105 & 6 & 99 \\
\hline 2006 & 544 & 299 & 245 & 90 & 75 & 15 & 106 & 6 & 100 \\
\hline 2007 & 626 & 345 & 281 & 123 & 113 & 10 & 139 & 8 & 131 \\
\hline 2008 & 613 & 338 & 275 & 124 & 115 & 9 & 152 & 9 & 143 \\
\hline Man hours (\%) & & 100 & & & 14 & & & 36 & \\
\hline
\end{tabular}

Lean manufacturing at the site exceeded the most optimistic expectations. It had a positive effect on every measurable operational parameter: cost per unit decreased, effectiveness and capacity utilisation improved, lead and cycle time dropped, inventory level on the shop floor decreased, processes became transparent, operational responsibility was better defined, and output increased. After many years of losses, these changes contributed considerably to the positive results from previous quarters. After streamlining the two main job shops, the management decided to implement lean manufacturing procedures for the related upstream processes. Tailoring (linked to sewing; 7\% of man-hours) and pressing (linked to welding; $13 \%$ of man-hours) also deserved attention. These two shops were the third and fourth most demanding in terms of manpower. As of 2008, lean manufacturing affected more than $80 \%$ of manufacturing operations, including end product storage. The new strategic target is to strengthen the company's position in Suzuki's supply chain and seek new opportunities in the rapidly expanding Central and Eastern European (CEE) automotive industry. 


\subsection{Lean implementation}

The method of lean implementation (initial training, setting up projects, implementation, rewards, intense communication first in a joint company meeting then through middle managers, team leaders, posters, and other printed and electronic channels) and the timing were practically the same for the two plants. However, there are some differences in process characteristics and in lean transition which are described and explained below.

Welding shop. The welding process is paced by robots and the work tasks are physically demanding. The company invested in welding robots some time before the transformation and continued investments during the transformation. The robots increased the level of automation in the welding shop, and they reduced the need for highly skilled workers (to one per cell), pushing the typical skill level towards semiskilled workers (the number of skilled welders reduced considerably during the years). Before the lean implementation started, there were already some cells in the production, but it was not the typical form of work organisation. Welding and material handling tasks were separated: there were workers for logistics processes in the welding shop. Production planner made decisions on short term production planning and scheduling. He was the 'bottleneck' what led to long lead times and many unplanned changeovers during the day, shortages in inventories, overloaded processes.

The main task in the initial phase of lean implementation was to install the new robots, streamline existing cells and supporting logistics processes, and change the working practices accordingly. Workers from different shifts and managers worked together in the first project. The cell (work content, layout and workload) was perfected and continuous material handling was replaced. The hourly material replenishments (milkrun) eliminated the need for material handlers, mainly females. This change is the main reason for the reduced ratio of women (see Table 2). Among the remaining women two of them are high-skilled welders. Some weeks after the set-off of the first project other projects were started in parallel. Before the lean projects workers got a preliminary introduction to their task and they themselves set objectives, methods (i.e., lean tools and principles), made transformation and analyzed results. They were completely self-sufficient, which were due to the few uncertainties in the changes.

Sewing shop. In contrast, in the sewing shop there was a much less transparent layout before the changes. The process is labour-intense, and the job requires unskilled people. There was no clear flow of material and information, and there were not dedicated areas for inventories (raw material, WIP, finished goods). Similarly to welding shop, the production planner was the 'bottleneck' in scheduling. Material handling was not a separated job, so every sewer was responsible for his/her own supply. The technology did not change in the last years.

The less transparent sewing process was the reason why it took three months to develop the first cell which later was rapidly followed by other cells. In the first project managers and head of sewers were delegated by the CEO to increase their commitment, but no other sewers were involved. Managers had to know more about the process, and the CEO wanted fast results to show evidence for everybody. Later, but not in the initial phase, the majority of workers were involved into the changes. Nevertheless, the final decisions in the project were made by the workers. They changed the workload and work content, and completely new cells and a process-oriented layout were created. Material handling was also reorganized: a new position, material handler, was created. This individual was responsible for carrying materials and finished products to and between workstations. Thus, sewers had more time to concentrate on the sewing itself. The higher productivity improvement achieved in sewing shop as compared to welding shop was the result of the more radical changes there. Finally, we should note again that managers were less familiar with the processes and tasks in sewing shop. Although the vast majority of workers in sewing shop are female the plant manager 
(who is more a manager than a professional sewer) and the technicians are males, and there are some male sewers, as well.

The management used similar rewards in the two job shops. When new cells reached the target volume for the first time, the group was invited for a dinner by the top managers. When they could maintain the target level for a week they received a bonus. As the CEO reported, women started to compete to be the first, and strived for going for the dinner. Males were not so enthusiastic about the dinner, they were more interested in bonus. Certainly, there were a limited number of people who could not and did not want to adjust to changes. These very few people were laid off from both job shops and from among managers.

The characteristics of the two job shops in the initial phase and transition processes are summarized in Table 3. The processes in the two job shops became very similar considering layout, scheduling, work methods etc. after applying lean principles. The real difference was in the initial process characteristics and the appropriate lean implementation approach.

Table 3

Original characteristics and changes in the two job shops

\begin{tabular}{|l|l|l|}
\hline \multicolumn{2}{|l|}{ Original characteristics } & Selding plant \\
\hline Production process & $\begin{array}{l}\text { Automated, machine-paced, } \\
\text { physically demanding }\end{array}$ & Manual, labour-intensive \\
\hline Managers' technical competences & Deep & Limited \\
\hline $\begin{array}{l}\text { Transparency of material and } \\
\text { information flow (compared to } \\
\text { each other) }\end{array}$ & More transparent & Less transparent \\
\hline Changes & \multicolumn{2}{|l|}{} \\
\hline Length of the first lean project & A bit less than 3 months & 3 months \\
\hline $\begin{array}{l}\text { Level of change (compared to } \\
\text { each other) }\end{array}$ & Moderate & Radical \\
\hline $\begin{array}{l}\text { Characteristics of changes } \\
\text { Position changes }\end{array}$ & $\begin{array}{l}\text { Minor layout changes, new welding } \\
\text { robots, minor load changes, logistics } \\
\text { changes (milkrun) }\end{array}$ & $\begin{array}{l}\text { Completely changed work } \\
\text { content, work load and new } \\
\text { logistics processes }\end{array}$ \\
\hline Skill requirements after change & - & Lower, semiskilled is enough \\
\hline Involvement in the initial change & Great proportion of affected workers & No change, semiskilled is enough \\
\hline $\begin{array}{l}\text { Involvement later in lean changes } \\
\text { Painly managers }\end{array}$ & Great proportion of affected workers & $\begin{array}{l}\text { Great proportion of affected } \\
\text { workers }\end{array}$ \\
\hline
\end{tabular}

\section{Construct of the model}

On the basis of the revealed elements of successful (lean) transformation policies, we built a model to analyse the factors determining perceptions of lean success (see Figure 1). The logic of our model is as follows. In general, higher commitment levels, stronger belief in the system being implemented, more communication and better work methods can increase the likelihood that workers will perceive the transformation as successful (with all coefficients expected to be positive). We expect that each element has direct and, via other variables, indirect effects on lean success. Finally, we should highlight at this point that the case company's lean production efforts have been successful in terms of both financial measures (profit, savings, etc.) and non-financial ones (e.g., operational measures). The latter measures were evaluated using our questionnaire and interviews.

In our model, in accordance with the literature, commitment is the key element of the perception of successful change. This is reflected in the "converging" arrows of the indirect effects. We have used Mowday et al.'s (1982) definition of commitment here. 
Belief can have a significant effect on perceptions of success. It is critical during the initial phase of any transformation process to make sure that employees without any personal experience believe in the new initiatives. Authentic communication regarding the conversion process and the organisation-wide vision can serve as a source of employee belief in the system being implemented. Enabling identification with company beliefs may enhance commitment among employees.

Communication is a key external element of the organisational change process. Communication about the roles of various individuals (Deming, 1986) and about projects, vision and strategy and achieved and targeted performance can facilitate success. As $\mathrm{Ng}$ et al. (2006) have discussed, good communication leads to greater worker commitment. Thus, it also has indirect effects on lean success.

People assess the success of the reorganisation processes based on their own experience, at least partially. If the new work methods and procedures improve people's own work (in terms of speed, quality, and ergonomics) and are used to effectively resolve everyday production problems, than they can have a positive effect on employee feelings of success. Additionally, the work method can have an indirect effect on lean success through commitment (de Treville and Antonakis, 2006).

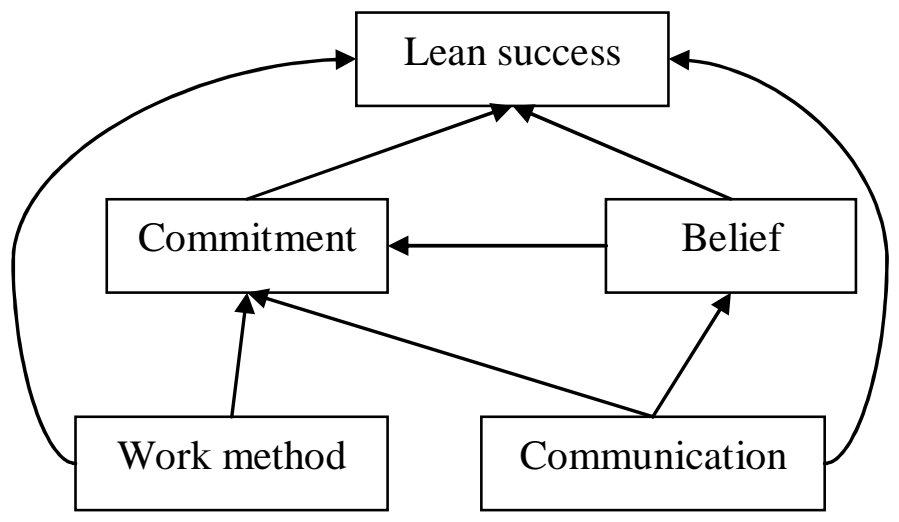

Fig. 1. Predictors of lean success

\section{Data analysis}

The model presented here was evaluated via path analysis using the SPSS 15.0 program. Path analysis allows us to examine the causal model as a set of multiple regression equations, one for each dependent variable, and we are able to determine its overall quality (Flynn and Saladin, 2001). The correlations between any two elements of the model can be separated into direct and indirect effects. Path coefficients are equivalent to standardised regression coefficients, so the statistical significance of each path coefficient can be determined using conventional t-tests (Rungtusanatham et al., 1998). Hence we will be able to determine which paths are relevant in our case. During the path analysis, we allow connections between independent variables, so multicollinearity is not an issue (Flynn and Saladin, 2001).

We have three regression equations in our model, one for lean success (with four independent variables represented by four direct incoming arrows from work method, commitment, belief and communication in Figure 1), one for commitment (with three variables represented by three incoming arrows from work method, communication and belief) and one for belief (with one variable represented by the incoming arrow from communication).

Because the number of workers surveyed is relatively small, we have limited the number of variables used. The questions used for the analysis are listed in Table 4. 
Table 4

Original variables and constructs used for the analysis

\begin{tabular}{|c|c|c|c|c|c|}
\hline $\begin{array}{c}\text { Constructs/model } \\
\text { variables }\end{array}$ & $\begin{array}{c}\text { Original variables } \\
\text { (1-6 scale, 1-total agreement, 6-total disagreement) }\end{array}$ & Avg. & $\begin{array}{l}\text { Standard } \\
\text { deviation }\end{array}$ & $\begin{array}{c}\text { Cronbach } \\
\text { alpha }\end{array}$ & $\begin{array}{c}\text { Construct } \\
\text { average }\end{array}$ \\
\hline Lean success & $\begin{array}{l}\text { My company is successful in implementing lean } \\
\text { production }\end{array}$ & 2.12 & 0.999 & & - \\
\hline \multirow{3}{*}{$\begin{array}{l}\text { Commitment } \\
\text { (feeling of } \\
\text { involvement) }\end{array}$} & We work together with managers to solve problems & 2.94 & 1.223 & \multirow{3}{*}{0.76} & \multirow{3}{*}{2.79} \\
\hline & I am ready to do more than expected & 2.41 & 1.200 & & \\
\hline & I have the opportunity to improve processes & 3.00 & 1.322 & & \\
\hline Belief & I believe in the importance of lean implementation & 2.44 & 1.118 & & - \\
\hline \multirow{2}{*}{ Work method } & $\begin{array}{l}\text { Since lean production was implemented, I have had to know } \\
\text { about more kind of operations }\end{array}$ & 2.30 & 1.274 & \multirow{2}{*}{0.82} & \multirow{2}{*}{2.43} \\
\hline & $\begin{array}{l}\text { Since lean production was implemented, I have had to do } \\
\text { more supplemental activities }\end{array}$ & 2.55 & 1.441 & & \\
\hline \multirow[b]{2}{*}{ Communication } & I was told why we were implementing lean production & 2.09 & 1.020 & \multirow[b]{2}{*}{0.84} & \multirow[b]{2}{*}{2.09} \\
\hline & $\begin{array}{l}\text { I was told when and how lean production would be } \\
\text { implemented }\end{array}$ & 2.12 & 0.883 & & \\
\hline
\end{tabular}

The degree of agreement with each statement was indicated using a 1 to 6 Likert scale (1total agreement, 2-agreement, 3-slight agreement, 4-slight disagreement, 5-disagreement, 6total disagreement), what did not allow the respondents to stay neutral; it forced them to adopt either a positive or a negative attitude. After verifying the reliability of the constructs, we used the averages of the original variables to create constructs where needed (Table 4). Next, we conducted a regression analysis of the three regression equations in our model for all bluecollar workers (83 workers) (Figure 2a).

Working from the literature review, we consider two contextual factors: job shop (process characteristics) and gender. As the " $b$ " and "c" portions of Figure 2 illustrate, the factors influencing success differ considerably between the different job shops. The difference is even stronger if we group participants based on gender (Figure $2 \mathrm{~d}$ and $2 \mathrm{e}$ ). The reason for this is that the opinions of women in welding are similar to the perceptions of the women employed in the sewing plant. However, their low numbers $(n=2)$ does not allow us to assume a clear gender-related explanation. A summary of these regression results is given in Table 5.

In the model for all workers, all of the regression equations are significant, and the explanatory power of the model is relatively high (0.25). Only the coefficient of the relationship between belief and commitment is not significant. Communication has the greatest total effect $(0.332)$ on feelings regarding the success of lean production, underlining the importance of communication to the lean transformation process. Work methods are also more important than commitment or belief, the implicit personal factors.

All three regression equations are significant for the sewing plant population, but the explanatory power of the model for lean success is much greater than that of the general model (with an increase from 0.25 to 0.43 ). However, only one of the four suggested factors directly affects the perception of success: belief (0.532). Communication has an indirect impact through belief (0.303). None of the remaining factors affects workers' perceptions. Although commitment is greatly affected by belief, it does not affect feelings of success.

Fundamentally different factors influence perceptions in the welding plant. Only two of the three regression equations (lean success and commitment) are significant, whereas it emerges that beliefs are not significant. Ultimately, only two factors affect the perception of lean success (0.36): the indirect effect of work method through commitment (0.728) and the direct effect of commitment (0.499).

a.Total sample 

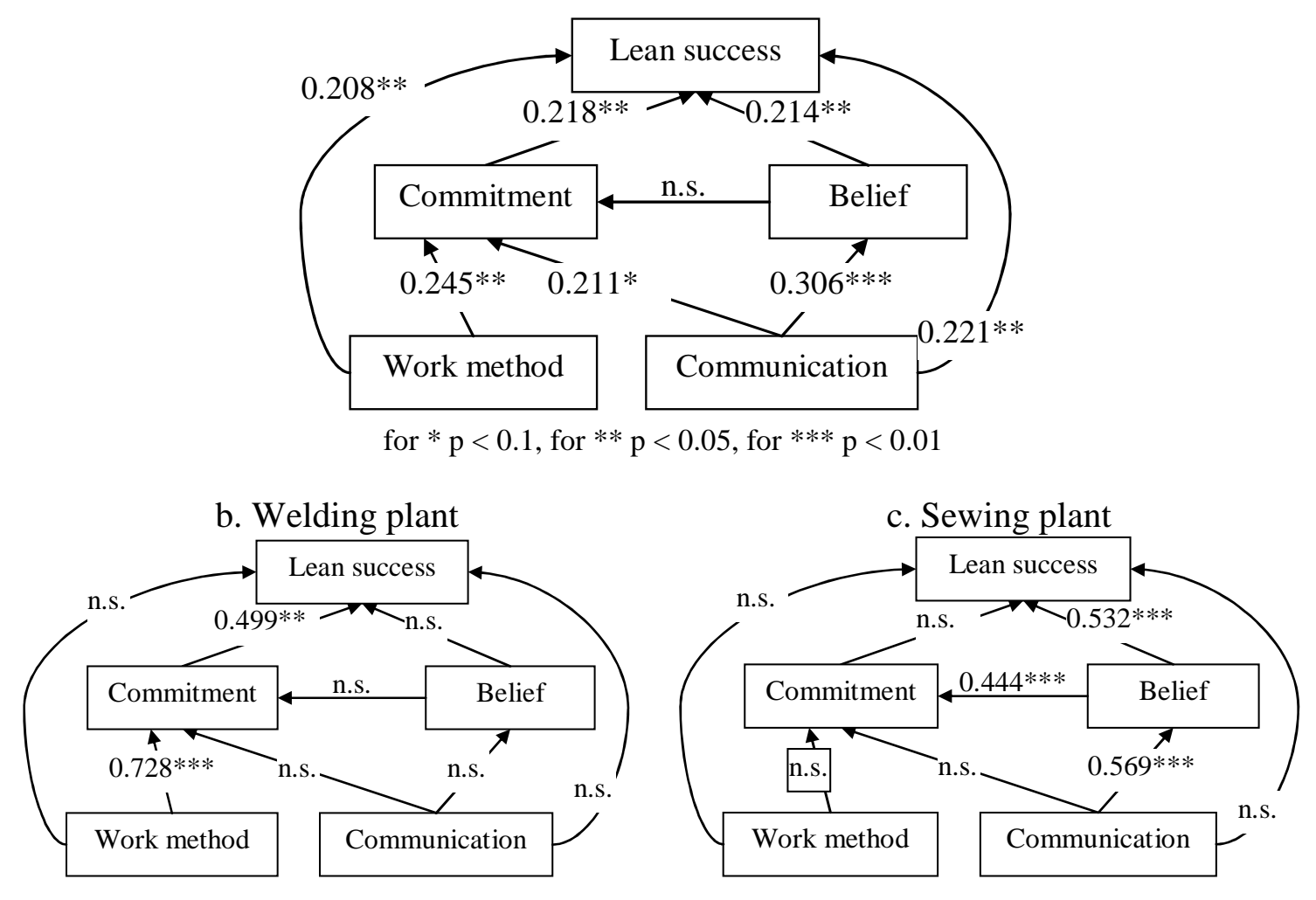

for $* \mathrm{p}<0.1$, for $* * \mathrm{p}<0.05$, for $* * * \mathrm{p}<0.01$
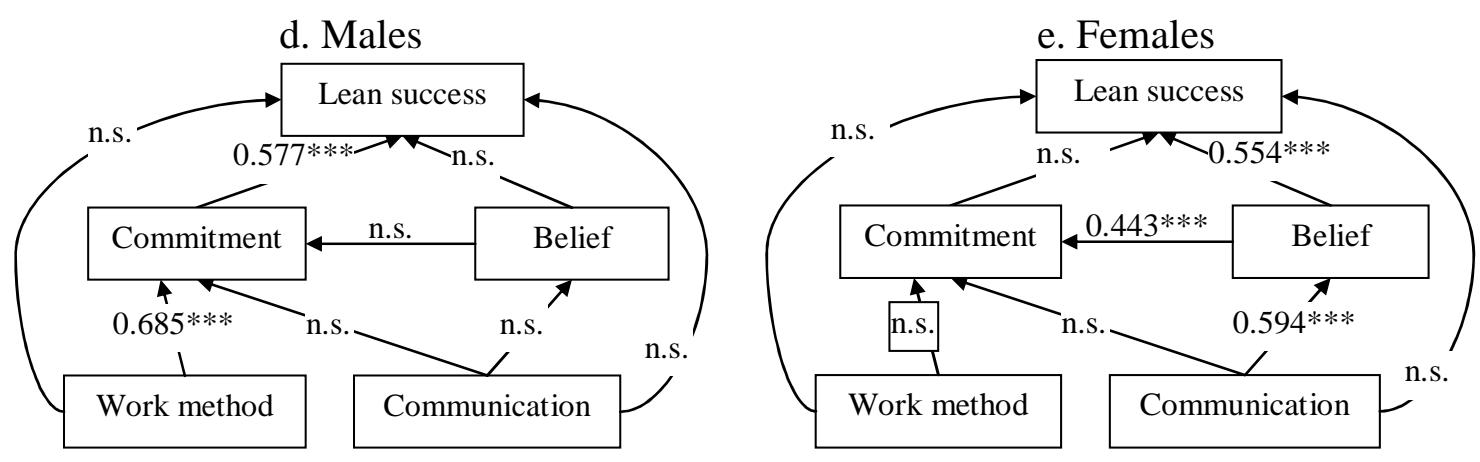

$$
\text { for } * \mathrm{p}<0.1, \text { for } * * \mathrm{p}<0.05, \text { for } * * * \mathrm{p}<0.01
$$

Fig. 2. Standardised coefficients of regressions (n.s.= not significant). ${ }^{1}$

As expected, there are minor differences between the influential factors for the sewers and the women in general and between those for the welders and the men in general. In the female-only model, like the general model, all of the regression equations are significant, and the explanatory power is even higher than in the general case $(0.42)$. Belief has the greatest effect by far (0.554) on feelings of success. Communication is also strong (0.329) and, through belief, has an indirect effect on feelings of success. The indirect effect of belief is "neutralised" by commitment.

The regression equation for belief is not significant for males. Nevertheless, the overall model fits the best for males (adjusted $\mathrm{R}^{2}$ is 0.46 ). The feeling of involvement is the best predictor of feelings of success (with a coefficient of 0.577), and the feeling of involvement is strongly influenced by the new work methods used in lean management (0.685). 
Table 5

Results of the path analysis (adjusted $\mathrm{R}^{2} \mathrm{~s}$, statistics regarding regression significance and total effects of the independent variables on lean success)

\begin{tabular}{|c|c|c|c|c|c|}
\hline & $\begin{array}{c}\text { Total sample } \\
\qquad(N=83)\end{array}$ & $\begin{array}{c}\text { Sewing plant } \\
(N=61)\end{array}$ & $\begin{array}{l}\text { Welding plant } \\
\qquad(N=22)\end{array}$ & $\begin{array}{c}\text { Females } \\
(N=63)\end{array}$ & $\begin{array}{l}\text { Males } \\
(N=20)\end{array}$ \\
\hline \multicolumn{6}{|c|}{ Regression results } \\
\hline Lean success & $\begin{array}{c}\mathrm{R}^{2}=0.25 \\
\left(7.415^{* * *}\right)\end{array}$ & $\begin{array}{l}\mathrm{R}^{2}=0.43 \\
(9.79 * * *)\end{array}$ & $\begin{array}{l}\mathrm{R}^{2}=0.36 \\
(3.957 * *)\end{array}$ & $\begin{array}{l}\mathrm{R}^{2}=0.42 \\
\left(11.45^{* * *}\right)\end{array}$ & $\begin{array}{l}\mathrm{R}^{2}=0.46 \\
(5.050 * * *)\end{array}$ \\
\hline Commitment & $\begin{array}{c}\mathrm{R}^{2}=0.11 \\
(4.249 * * *)\end{array}$ & $\begin{array}{l}\mathrm{R}^{2}=0.16 \\
\left(4.53^{* * *}\right)\end{array}$ & $\begin{array}{l}\mathrm{R}^{2}=0.36 \\
\left(5.006^{* *}\right)\end{array}$ & $\begin{array}{l}\mathrm{R}^{2}=0.16 \\
(4.69 * * *)\end{array}$ & $\begin{array}{l}\mathrm{R}^{2}=0.33 \\
(4.161 * *)\end{array}$ \\
\hline Belief & $\begin{array}{l}\mathrm{R}^{2}=0.08 \\
(8.135 * * *)\end{array}$ & $\begin{array}{c}\mathrm{R}^{2}=0.31 \\
(27.34 * * *)\end{array}$ & $\begin{array}{c}\mathrm{R}^{2}=-0.02 \\
(0.655)\end{array}$ & $\begin{array}{l}\mathrm{R}^{2}=0.34 \\
(32.12 * * *)\end{array}$ & $\begin{array}{c}\mathrm{R}^{2}=-0.06 \\
(0.000)\end{array}$ \\
\hline \multicolumn{6}{|l|}{ Total effects } \\
\hline Commitment & 0.218 & - & 0.499 & - & 0.577 \\
\hline Belief & 0.214 & 0.532 & - & 0.554 & - \\
\hline Communication & 0.332 & 0.303 & - & 0.329 & - \\
\hline Work method & 0.261 & - & 0.363 & - & 0.395 \\
\hline
\end{tabular}

$\mathrm{F}$ test results in brackets; for $* \mathrm{p}<0.1$, for $* * \mathrm{p}<0.05$, and for $* * * \mathrm{p}<0.01$

\section{Discussion of results and implications}

In our research, we have identified the critical determinants of workers' perceptions of successful lean implementation. We have found that belief, commitment, work method and communication all have a considerable direct effect on workers' perceptions regarding lean success. Moreover, work method and communication also have an indirect impact through commitment and through commitment and belief, respectively. There is only one path from belief to commitment, which is not significant.

Several lean-related changes occurred at our case company: cells were implemented in the sewing plant and reorganized in welding plant, logistics were reorganised in both welding and sewing plants to considerably reduce the time and distances involved in material collection, kanban systems were implemented, visual controls were integrated into each work station, and employees were motivated financially and socially. All of these changes happened during the course of months and involved the majority of the management and some workers. For example, the physical transformation of the first project's production cell in welding plant took place on an early Saturday morning with the CEO, the majority of top managers, maintenance employees and affected workers. Workers were deeply surprised seeing their managers replacing tables, equipment, and other stuff on the basis of instructions shaped in previous weeks by workers (although managers were involved into the project from the very beginning, they refrained from making any decisions even if they had their own opinion).

Such a large change would necessarily evoke some kind of reaction from company employees. However, because the first results of the changes emerged very quickly, these individuals were persuaded that the new ways of working are more efficient than the old ones. So the better work method itself increased feelings of success. The employees also had some "changeover" time to get used to the new processes and were informed about and trained in the new tasks. Furthermore, because affected workers were directly involved initially in the transformation and many more later on, and because all employees were later asked about their ideas for how to further improve their workplace, so the level of participation and decentralisation increased considerably at the company. The workers became committed. Communication also worked well. People received feedback on their results from foremen, plant managers and CEO with varying frequency. The information about their own results increased commitment and belief in lean systems and positively affected their feelings regarding the success of those systems. As we have seen from our case company, lean work 
methods and intense communication (both about changes beforehand and afterwards and about the results of everyday work) can build belief in and commitment to lean systems and lead to feelings of success.

As we noted earlier, patterns of success factors and their relationships differ between job shops. In the following section, we use contextual factors revealed in literature review (2.4.) to explain the differences. We consider the effect of process characteristics (7.1.), the impact of gender (7.2.), and the role of national context (7.3.). Organisational elements are discussed throughout the paper, especially in section 4, 7.1., and 7.2.

\subsection{The effect of process characteristics}

The perceptions and influencing factors are very different between different job shops (Figures 2b and 2c, Appendix 1 and 2). Perceptions of individuals in welding are influenced only by commitment and work method, whereas in sewing are influenced by belief and communication.

As we discussed earlier, changes in the welding plant did not affect workers' positions significantly (only of those who were high-skilled, but that was more the consequence of the new technology than of lean implementation), simply reducing unnecessary movements. Thus, employees in the welding plant could see the positive impact of the changes in the work method. Workers could contribute with their ideas (regarding targets, methods) from the initial phase which made them more active in creating new ideas and indicated the success of lean manufacturing (2.14 on a 1-6 scale with 1 indicating total agreement and 6 indicating total disagreement with the statement). The on-hand experience regarding involvement and fast results is the reasons why they did not need to believe (we obtained a value of 3.05, which is between slight agreement and slight disagreement) in the lean system.

In the sewing department, changes were more radical. Employees have generally felt less involved, simply because they have not been involved (committed). Without any experience in the initial phase, communication of intended changes, the results in terms of increased output and productivity persuaded them to believe (2.22) in the success of lean systems (2.12).

In our case company the scope and focus of lean changes were "determined" by the initial process characteristics. In other words, the managerial approach of lean projects and factual intervention were shaped by the original (i.e., before lean projects) work organisation. These differences are reflected in the perceptions of employees:

a. The more transparent process in welding plant led to a moderate lean transformation where workers were involved and immediately saw the results of the new methods. People in such an environment are more likely to understand and appreciate how the new system works. Workers' perceptions obviously show that they combine lean success with involvement and work methods: they simply map their experience. Since they perceive advantages of the new system right from the beginning, the role of belief is less important.

b. The less transparent process in sewing plant led to a radical lean transformation where workers were not involved and did not apply new work methods from the beginning. During the renewal people had less of a chance to learn about the whole system, its potential or its effects. In such an environment belief in the system and its actors became crucial. The other pillar was communication: managers had to persuade workers that the changes, actions and efforts are good for them.

Table 6 summarises these results. In our study we defined success factors that lead workers to feel lean management to be a successful management tool. Of course, workers perceptions are usually being shaped by managerial interventions, and hence they are reflecting those. Lean success factors differ in distinct contextual settings: workers perceive 
work method and commitment as main success factors in moderate change; and communication and belief in radical change. The level of lean change (and so the level and art of managerial intervention) is "determined" by the initial process characteristics.

Although we are very cautious about providing general implications, the initial settings and the way of conversion to a lean system differs from case to case, both job shops owned by the case company represents a typical (moderate and radical) lean transformation.

Table 6

Relationship between characteristics of work environment and influential lean success factors

\begin{tabular}{|c|c|c|c|}
\hline Process characteristics & Welding plant & & Sewing plant \\
\hline Transparency of initial process & More transparent & $\leftarrow \rightarrow$ & Less transparent \\
\hline Production process & Machine paced & $\leftarrow \rightarrow$ & Labour intensive \\
\hline Level of lean change & Moderate & $\leftarrow \rightarrow$ & Radical reorganisation \\
\hline Main success factors & $\begin{array}{r}\text { Work method, } \\
\text { commitment }\end{array}$ & & $\begin{array}{l}\text { Communication, } \\
\text { belief }\end{array}$ \\
\hline
\end{tabular}

We should add, that it does not mean that workers did not have enough communication in the welding shop (actually they felt they received more, see Appendix 1 and 2), but that did not strengthen their feeling of lean success. The role of communication can be seen as a "qualifier" criterion.

\subsection{The impact of gender}

Based on the geographical separation of individuals in the company by gender, we cannot avoid comparing the reactions and perceptions of males and females. Beyond psychological (stereotypical) differences (7.2.1.) gender is embedded in the organisational structure through gender segregation and gender hierarchy (7.2.2.).

\subsubsection{Image of the case company - stereotypical gender approach}

What we might say on the basis of our results that the main reason behind the different perceptions lie in initial process characteristics. For example, the fact that females were only more or less committed (the average construct value is 2.9 , and 3 means slight agreement) is due to the lack of extensive involvement in the initial phases of lean in sewing plant. Furthermore, the lack of on-hand experience is also reflected in the perception for belief: the scores are significantly better for females than for males (the average variable value is 2.18 for women and 3.25 for men, $\mathrm{F}=16.5, \mathrm{p}=0.000$ ).

Beside process-based explanation we also have some phenomenon that can be explained by stereotypical gender approach. This stereotypical approach of genders relies on differences in feminine and masculine values (Linstead et al., 2005; Neil and Snizek, 1987; Hofstede, 1983, Grunig et. al., 2000). According to this approach females are more emotional than males. They are motivated by their emotions and beliefs. Males are considered to be directed by logic to behave more rationally. They do not accept things as given. These differences in male and female values might have contributed to the distinct gender patterns of our general model. The gender-based separation showed even stronger difference than the process-based (compare Figure 2c and 2e).

Those women who are true believers (gave the highest answer for belief) evaluated every aspect of lean transformation much better than others did. This also holds for the two women who work in the welding plant, who both indicated a value of 1 . Furthermore, the CEO reported that women were enthusiastic about the dinner and men were interested in only the extra money. These imply that women could be approached through their emotions in the case company. 
In this case stereotypical gender approach can explain some phenomenon and could have contributed to the successful lean transition. Masculine attitudes were exaggerated during a moderate change process. Because of the extent of the change, men could easily understand the change process and its direct effects. They were not confused by the transformation. The workplace remained comfortable for them. Moderate changes also provided a good opportunity for managers to involve employees. Men's commitment was boosted by involvement and by opportunities for them to experience the benefits of the new system almost immediately. Feminine values fit radical changes where the role of belief is the most important. Women trusted their foremen and managers because the changes were hard to review. Instead of needing personal experience, they were more likely to rely on the managers' feedback about results targeted. This feedback convinced them that the system and managers the company had chosen were appropriate.

Altogether, the stereotypical approach match very well the required process changes in the two plants. Although there are only a few empirical evidence of this stereotypical behaviour in our hands at the case company, and the two plants are very gender homogenous to separate the effect of process and gender, the huge differences in the results support or at least do not go against the stereotypical approach.

\subsubsection{Image of the case company - modern gender research}

Being female or male does not necessarily create feminine or masculine behavior (Ely and Padavic, 2007). Nevertheless, in the Raba case we felt that the company culture is rather "conservative", meaning that both males and females are expected to behave according to traditional gender values.

The organisation is gendered in the classical sense: there is a high level of gender segregation and gender hierarchy is also present (Acker and Van Houten, 1974; Acker, 1990). The segregation is mainly due to stereotypical gender jobs in the two job shops: welder positions are usually occupied by males and sewing is considered as female job. Interesting fact, for example, that in Hungary the word 'sewer' includes that the given person is a female, no word exists for a male sewer. This gender segregation is, however, not an intended managerial effort. They hire welding women and sewing men (they currently have both) but only if they have such an applicant. They look only at the capabilities during the recruitment. A sign of gender hierarchy is that the top of the organisation is dominated by male engineers. This exclusive dominance can be originated in the stereotypical gender coding of the field of (mechanical) engineering and it is continuously being reproduced society-wide. Since the engineering positions are usually dominated by males, they are those who have first hand lean experience. So, in the new settings the gender hierarchy can be strengthened if managerial position requires both production (technology) and lean experience as well.

We mentioned in 4.2. (and see also Table 2) that the welding shop became even more gender homogeneous after the lean transformation. The number of males in welder and maintenance positions increased, but the number of females decreased due to the reorganisation of material handling. In the sewing plant, that has been already gender homogeneous, the gender "ratio" did not change: the number of male workers increased with the number of females. Based on this, we state that a change process most likely can lead to even stronger gender segregation, if the value-adding activity is gender coded and the supplement positions are "quasi" gender-neutral (and are also occupied accordingly). The reason behind is that during a lean transition companies strive to reorganize and improve the efficiency of main and supplement activities and even an increased capacity can be served by fewer employees in the supplement area.

Modern gender research does not allow us to clarify the effects of lean success factors and explain our model. It shows that lean management does not "melt" gender segregation and 
hierarchy that already embedded in organisation (or in social context). Gender hierarchy can get even worse if top positions are tied to lean experience and in special circumstances also jobs can get more gender homogenous. On the other hand, in spite of the gender segregation the welding shop and the sewing shop were developed into the same direction: they have similar, cell-based lean processes relying on semiskilled workers, who have been involved into improvement efforts similarly in later phases of lean transformation. That is, the top management's approach to workers was not based on stereotypes.

\subsection{National context}

It is questionable whether the CEE environment yields different results than would be achieved in other developed countries. We feel that the possible differences in lean implementation as compared to other countries might not be too large because lean transformations usually involve a well developed process and because managers learn the methodology from international consultants. The CEO is a good example for this: he gained his experience in multinational environment and attended several international training.

Table 7 suggests that the general labour market indicators in Hungary for males and females are similar to those in other European countries. Also, the employment characteristics for the two genders are the same in Hungary as elsewhere in Europe (Medgyesi and Róbert, 1998). So, our model considering process, lean implementation and gender characteristics does not reflect any specific national factor.

Table 7

Labour market characteristics in Hungary compared to those for EU countries (rounded avarage for the period)

\begin{tabular}{|l|c|c|c|}
\hline & $\begin{array}{c}\text { Female labour force } \\
\text { (percentage of total labour } \\
\text { force, 2006-2008) }\end{array}$ & $\begin{array}{c}\text { Female positions } \\
\text { (percentage of total legistlators, } \\
\text { senior officers and managers, } \\
\text { 2006-2007) }\end{array}$ & $\begin{array}{c}\text { Gender income ratio } \\
\text { (ratio of estimated female to } \\
\text { male earned income globally, } \\
\text { 2006-2007) }\end{array}$ \\
\hline Austria & $46^{*}$ & 28 & 0.40 \\
\hline Czech Republic & 44 & 29 & 0.59 \\
\hline Finland & 48 & 30 & 0.73 \\
\hline Germany & $43^{*}$ & 38 & 0.60 \\
\hline Hungary & 46 & 36 & 0.71 \\
\hline Poland & 45 & 34 & 0.60 \\
\hline
\end{tabular}

Source: IMD World Competitiveness Center (worldcompetitiveness.com)

*2008 data are not available

Nevertheless, the attitude of workers may be different; think, for example, of the problems experienced implementing lean manufacturing in Japan versus in the US. News in Hungarian journals shows that Hungarian people are less keen on lifelong learning than is the case in other developed countries or even other CEE countries (GKI, 2007, p. 159).

\section{Limitations}

The case company seems to be a perfect subject to analyze success factors of lean implementation and to compare the impact of process and genders. However, our findings contain some obvious limitations.

The personalities of job shop managers, who are the direct bosses, were different, and this may have distorted our results.

Furthermore, there were not enough data for the path analysis of the males for us to consider our results really robust, and we investigated only one organisation in detail. Although the explanatory power of our model can be considered quite high, these limitations 
indicate that there may be other important variables than the studied factors that influenced feelings of success. Feelings of success can also be affected by the intensification and depth of the transformation process: the effects of rapid and deep changes on feelings and perceptions can be grasped and explained more easily, as in our case, than those of long, fragmented, and shallow conversion.

There were no available qualitative scales for workers' perceptions of lean changes. We combined the related OM knowledge with that of other fields, but further research should improve the validity and reliability of the measures and help to complete the proposed model.

Finally, because of the type of research methodology used here, the results are not generalisable. However, the combination of contextual issues and factors influencing perceptions clearly deserves more attention.

\section{Conclusions}

Past research has not examined workers' perceptions regarding the success of lean implementation. Our study paints an interesting picture of how workers' perceptions and influential success factors vary in particular contexts. Based on the literature review, we identified the critical intrinsic factors (commitment, belief) and external factors (lean work method, communication) affecting the success of lean implementation from workers' point of view.

To increase the possibility of lean transformation success, it is important for employees to develop higher commitment levels, experience stronger beliefs, be exposed to greater communication and cultivate better work methods. Managers should also consider contextual factors, because patterns of main success factors differ in different environment.

Consistent with the literature, it appears that gender and especially process characteristics can have a considerable effect on worker perceptions. Process characteristics define the way how lean can be implemented successfully. More transparent process allows moderate lean change and this setting provides the opportunity of involvement and fast feedback (e.g., work methods are useful, improving operational measures): workers regard these as key factors in assessing lean success. Less transparent process requires radical lean reorganisation. In this context belief and communication play crucial role in shaping workers' perceptions. Our findings, based on gender segregation of the two job shops, support the idea that the stereotypical gender values can intensify the impact of factors related to the particular process type. But we have to admit it might be because of the very distinct and stereotype gender segregation (resulting in almost gender homogenous workplaces, especially in case of the "women jobs").

We do not state that beside process-related factors (e.g., communication or belief during moderate change) the other elements of our model are not important factors, but based on the case we argue that they certainly do not have high impact on the feeling of success.

Lean implementation also shows that gender hierarchy can encapsulate if top managers are required to have professional (e.g., engineering) and lean experience. In special circumstances also whole job shops can get more gender homogenous.

Although lean production was seen as a success at both job shops associated with the case company, one may argue that that the perceived success of bottom-line changes could have been enhanced: managers could have emphasized those factors that do not come directly from process characteristics.

As we have pointed out, in the sewing plant, the radical nature of the conversion process made it difficult for managers to involve employees, and for workers to follow shop floor changes and to understand the new system. Here, the challenge is to find ways to involve workers from the very beginning that do not slow down the implementation process and that do not require too much additional resources. To switch from an approach guided by quick 
gains and rapid conversion to one that will likely be slower and demand more resources may be economically irrational.

Men in the welding plant perceived communication to be better than women did, and they also saw the greatest improvements related to lean systems (Appendix 1 and 2). In spite of its importance, communication did not affect men's feelings regarding success. However, in the welding plant, communication seemed to be one of the keys to successful lean changes ("qualifier" criterion).

Based on these findings we cautiously suggest that employee perceptions can clearly be influenced by our examined factors if moderate/radical, but not necessarily lean changes reshape shop floor activities. Further research should, for example, clarify the impact of the introduction of completely new technology or expert-led and project-based systems (e.g., six sigma). Again, we would like to underscore that more empirical work is required to investigate contextual issues (e.g., how males react to radical changes and/or how females behave during a time of moderate change).

In this case changes took place in short time and resulted great benefits. This "extreme situation" of the company allow us to differentiate between success factors and consider how they can be consciously managed for different contingencies as suggested by Eisenhardt (1989). However, our study only focused on short-term effects. Little is known about how the importance of these factors evolves over time. We believe that (enhancing) feelings of success during the lean implementation phase on the shop floor level can have a positive long-term impact. If lean implementation is perceived to be successful, it will be easier to encourage employees to accept the system and change the organisational culture to make lean initiatives sustainable.

\section{Acknowledgment}

Support for this research comes from the Hungarian Research Funds (OTKA, T 049147), the Bolyai János Research Scholarship program, and the foundation Together for Future Workplaces. 


\section{Appendix}

Appendix 1. Original variables and constructs used for the analysis - welding plant

\begin{tabular}{|c|c|c|c|c|c|}
\hline $\begin{array}{l}\text { Constructs/model } \\
\text { variables }\end{array}$ & $\begin{array}{c}\text { Original variables } \\
\text { (1-6 scale, 1-total agreement, 6-total disagreement) }\end{array}$ & Avg. & $\begin{array}{l}\text { Standard } \\
\text { deviation }\end{array}$ & $\begin{array}{c}\text { Cronbach } \\
\text { alpha }\end{array}$ & $\begin{array}{l}\text { Construct } \\
\text { average }\end{array}$ \\
\hline Lean success & $\begin{array}{l}\text { My company is successful in implementing lean } \\
\text { production }\end{array}$ & 2.14 & 1.167 & & 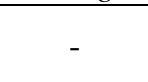 \\
\hline \multirow{3}{*}{$\begin{array}{l}\text { Commitment } \\
\text { (feeling of } \\
\text { involvement) }\end{array}$} & We work together with managers to solve problems & 2.68 & 0.646 & \multirow{3}{*}{0.52} & \multirow{3}{*}{2.42} \\
\hline & I am ready to do more than expected & 2.09 & 1.065 & & \\
\hline & I have the opportunity to improve processes & 2.50 & 0.802 & & \\
\hline Belief & I believe in the importance of lean implementation & 3.05 & 1.430 & & - \\
\hline \multirow[b]{2}{*}{ Work method } & $\begin{array}{l}\text { Since lean production was implemented, I have had to know } \\
\text { about more kind of operations }\end{array}$ & 2.32 & 1.492 & \multirow{2}{*}{0.75} & \multirow{2}{*}{2.27} \\
\hline & $\begin{array}{l}\text { Since lean production was implemented, I have had to do } \\
\text { more supplemental activities }\end{array}$ & 2.23 & 1.660 & & \\
\hline \multirow[b]{2}{*}{ Communication } & I was told why we were implementing lean production & 1.86 & 0.640 & \multirow[b]{2}{*}{0.86} & \multirow[b]{2}{*}{1.73} \\
\hline & $\begin{array}{l}\text { I was told when and how lean production would be } \\
\text { implemented }\end{array}$ & 1.59 & 0.666 & & \\
\hline
\end{tabular}

Appendix 2. Original variables and constructs used for the analysis - sewing plant

\begin{tabular}{|c|c|c|c|c|c|}
\hline $\begin{array}{c}\text { Constructs/model } \\
\text { variables }\end{array}$ & $\begin{array}{c}\text { Original variables } \\
\text { (1-6 scale, 1-total agreement, 6-total disagreement) }\end{array}$ & Avg. & $\begin{array}{l}\text { Standard } \\
\text { deviation }\end{array}$ & $\begin{array}{c}\text { Cronbach } \\
\text { alpha }\end{array}$ & $\begin{array}{l}\text { Construct } \\
\text { average }\end{array}$ \\
\hline Lean success & $\begin{array}{l}\text { My company is successful in implementing lean } \\
\text { production }\end{array}$ & 2.12 & 0.940 & & 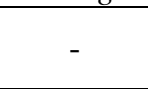 \\
\hline \multirow{3}{*}{$\begin{array}{l}\text { Commitment } \\
\text { (feeling of } \\
\text { involvement) }\end{array}$} & We work together with managers to solve problems & 3.07 & 1.375 & \multirow{3}{*}{0.78} & \multirow{3}{*}{2.93} \\
\hline & I am ready to do more than expected & 2.52 & 1.232 & & \\
\hline & I have the opportunity to improve processes & 3.19 & 1.432 & & \\
\hline Belief & I believe in the importance of lean implementation & 2.22 & 0.892 & & - \\
\hline \multirow{2}{*}{ Work method } & $\begin{array}{l}\text { Since lean production was implemented, I have had to know } \\
\text { about more kind of operations }\end{array}$ & 2.30 & 1.197 & \multirow{2}{*}{0.86} & \multirow{2}{*}{2.48} \\
\hline & $\begin{array}{l}\begin{array}{l}\text { Since lean production was implemented, I have had to do } \\
\text { more supplemental activities }\end{array} \\
\end{array}$ & 2.67 & 1.349 & & \\
\hline \multirow[b]{2}{*}{ Communication } & I was told why we were implementing lean production & 2.19 & 1.121 & \multirow[b]{2}{*}{0.83} & \multirow[b]{2}{*}{2.23} \\
\hline & $\begin{array}{l}\text { I was told when and how lean production would be } \\
\text { implemented }\end{array}$ & 2.27 & 0.887 & & \\
\hline
\end{tabular}

Appendix 3. Original variables and constructs used for the analysis - males

\begin{tabular}{|c|c|c|c|c|c|}
\hline $\begin{array}{c}\text { Constructs } / \text { model } \\
\text { variables }\end{array}$ & $\begin{array}{c}\text { Original variables } \\
\text { (1-6 scale, 1-total agreement, 6-total disagreement) }\end{array}$ & Avg. & \begin{tabular}{|l|} 
Standard \\
deviation
\end{tabular} & $\begin{array}{c}\text { Cronbach } \\
\text { alpha }\end{array}$ & $\begin{array}{c}\text { Construct } \\
\text { average }\end{array}$ \\
\hline Lean success & $\begin{array}{l}\text { My company is successful in implementing lean } \\
\text { production }\end{array}$ & 2.25 & 1.164 & & 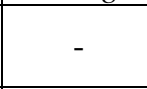 \\
\hline \multirow{3}{*}{$\begin{array}{l}\text { Commitment } \\
\text { (feeling of } \\
\text { involvement) }\end{array}$} & We work together with managers to solve problems & 2.65 & 0.671 & \multirow{3}{*}{0.69} & \multirow{3}{*}{2.40} \\
\hline & I am ready to do more than expected & 2.20 & 1.056 & & \\
\hline & I have the opportunity to improve processes & 2.35 & 0.587 & & \\
\hline Belief & I believe in the importance of lean implementation & 3.25 & 1.118 & & - \\
\hline \multirow{2}{*}{ Work method } & $\begin{array}{l}\text { Since lean production was implemented, I have had to know } \\
\text { about more kind of operations }\end{array}$ & 2.20 & 1.508 & \multirow{2}{*}{0.84} & \multirow{2}{*}{2.15} \\
\hline & $\begin{array}{l}\text { Since lean production was implemented, I have had to do } \\
\text { more supplemental activities }\end{array}$ & 2.10 & 1.483 & & \\
\hline \multirow[b]{2}{*}{ Communication } & I was told why we were implementing lean production & 1.95 & 0.605 & \multirow[b]{2}{*}{0.84} & \multirow[b]{2}{*}{1.80} \\
\hline & \begin{tabular}{|l|} 
I was told when and how lean production would be \\
implemented
\end{tabular} & 1.65 & 0.671 & & \\
\hline
\end{tabular}

Appendix 4. Original variables and constructs used for the analysis - females

\begin{tabular}{|l|l|c|c|c|c|}
\hline $\begin{array}{c}\text { Constructs/model } \\
\text { variables }\end{array}$ & \multicolumn{1}{|c|}{ Original variables } & Avg. & $\begin{array}{c}\text { Standard } \\
\text { deviation }\end{array}$ & $\begin{array}{c}\text { Cronbach } \\
\text { alpha }\end{array}$ & $\begin{array}{c}\text { Construct } \\
\text { average }\end{array}$ \\
\hline Lean success & $\begin{array}{l}\text { My company is successful in implementing lean } \\
\text { production }\end{array}$ & 2.08 & 0.946 & & - \\
\hline Commitment & We work together with managers to solve problems & 3.07 & 1.351 & 0.77 & 2.92 \\
\hline
\end{tabular}




\begin{tabular}{|l|l|c|c|c|c|}
\hline $\begin{array}{l}\text { feeling of } \\
\text { involvement) }\end{array}$ & I am ready to do more than expected & 2.47 & 1.241 & & \\
\cline { 2 - 4 } Belief & I have the opportunity to improve processes & 3.22 & 1.427 & & \\
\hline \multirow{3}{*}{ Work method } & $\begin{array}{l}\text { Since lean production was implemented, I have had to know } \\
\text { about more kind of operations }\end{array}$ & 2.18 & 0.904 & & \multirow{2}{*}{0.200} \\
\cline { 2 - 4 } & $\begin{array}{l}\text { Since lean production was implemented, I have had to do } \\
\text { more supplemental activities }\end{array}$ & 2.69 & 1.409 & \multirow{2}{*}{0.81} & 2.52 \\
\hline \multirow{2}{*}{ Communication } & I was told why we were implementing lean production & 2.15 & 1.123 & \multirow{2}{*}{0.84} & \multirow{2}{*}{2.19} \\
\cline { 2 - 4 } & $\begin{array}{l}\text { I was told when and how lean production would be } \\
\text { implemented }\end{array}$ & 2.23 & 0.902 & \\
\hline
\end{tabular}




\section{References}

Abrahamsson, L., 2001. Gender-based learning dilemmas in organizations. Journal of Workplace Learning 13 (7-8), 298-307.

Abdulmalek, F.A., Rajgopal, J., 2007. Analyzing the benefits of lean manufacturing and value stream mapping via simulation: A process sector case study. International Journal of Production Economics 107 (1), 223-236.

Acker, J., Van Houten, D.R., 1974. Differential recruitment and control: the sex structuring of organizations. Administrative Science Quarterly 19 (2), 152-163.

Acker, J., 1990. Jobs, bodies: a theory of gendered organizations. Gender and Society 4 (2), 139-158.

Ahmad, S., Schroeder, R.G., Sinha, K.K., 2003. The role of infrastructure practices in the effectiveness of JIT practices: implications for plant competitiveness. Journal of Engineering and Technology Management 20 (3), 161-191.

Armenakis, A.A., Bernerth, J.B., Pitts, J.P., Walker, H.J., 2007. Organizational Change Recipients' Beliefs Scale. Development of an Assessement Instrument. The Journal of Applied Behavioral Science 43 (4), 481-505.

Berggren, C., 1993. Lean production - the end of history, Work, Employment \& Society 7 (2), 163-188.

Bhasin, S., Burcher, P., 2006. Lean viewed as a philosophy. Journal of Manufacturing Technology Management 17 (1), 56-72.

Birdi, K., Clegg, C., Patterson, M., Robinson, A., Stride, C.B., Wall, T.D., Wood, S.J., 2008. The Impact of Humans Resource and Operational Management Practices on Company Productivity. Personnel Psychology 61 (3), 467-501.

Brown, K.A., Mitchell, T.R., 1992. A Comparison of Just-in-time and Batch Manufacturing: The Role of Performance Obstacles. The Academy of Management Journal , 34 (4), 906-917.

Browning, T.R., Heath, R.D., 2009. Reconceptualizing the effects of lean on production costs with evidence from the F-22 program. Journal of Operation Management 27 (1), 23-44.

de Treville, S., Antonakis, J., 2006. Could lean production job design be intrinsically motivating? Contextual, configurational, and levels-of-analysis issues. Journal of Operations Management 24 (2), 99-123.

Dawson, P., 1994. Quality Management: Beyond the Japanese Model. International Journal of Quality and Reliability Management 11 (7), 54-59.

Demeter, K., Gelei A., Jenei I., 2006. The effect of strategy on supply chain configuration and management practices on the basis of two supply chains in the Hungarian automotive industry. International Journal of Production Economics 104 (2), 555-570. 
Deming, W.E., 1986. Out of crisis. MIT Press, Cambridge.

Eisenhardt, K.M., 1989. Building Theories from Case Study Research. Academy of Management Review 14 (4), 532-550.

Ely, R., Padavic, I., 2007. A feminist analysis of organizational research on sex differences. Academy of Management Review 32 (4), 1121-1143.

Farris, J.A., Van Aken, E.M., Doolen, T.L., Worley, J., 2009. Critical success factors for human resource outcomes in Kaizen events: An empirical study. International Journal of Production Economics 117 (1), 42-65.

Flynn, B.B., Saladin, B., 2001. Further evidence on the validity of the theoretical models underlying the Baldridge criteria. Journal of Operations Management 19 (6), 617-652.

Forza, C., 1996. Work organizations in lean production and traditional plants. What are the differences? International Journal of Operations and Production Management 16 (2), 42-62.

GKI, 2007. Versenyképességi évkönyv 2007. GKI Gazdaságkutató Zrt, http://www.gki.hu/docs/gki_versenykepessegi_2007.pdf, (accessed $5^{\text {th }}$ April 2008)

Grunig, L.A., Toth, E.L., Hon, L.C., 2000. Feminist Values in Public Relations. Journal of Public Relations Research 12 (1), 49-68.

Hakim, C., 1991. Grateful slaves and self-made women: fact and fantasy in women's work orientation. European Sociological Review 7 (2), 101-121.

Hines, P. Holweg, M., Rich, N., 2004. Learning to evolve: A review of contemporary lean thinking. International Journal of Operations and Production Management 24 (10), 994-1011.

Hines, P., Taylor, D., 2000. Going lean. Lean Enterprise Research Centre, Cardiff.

Hofstede, G., 1983. Natural Cultures in Four Dimensions: A Research-based Theory of Cultural Differences among Nations. International Studies of Management and Organization 13 (1-2), 46-74.

Huber, V.L., Brown, K.A., 1991. Human Resources Issues in Cellular Manufacturing: A Sociotechnical Analysis. Journal of Operations Management 10 (1), 138-159.

Hyer, N.L., Brown, K.A., Zimmerman, S., 1999. A socio-technical system approach to cell design: case study and analysis. Journal of Operations Management 17 (2), 179-203.

IMD World Competitiveness Center (worldcompetitiveness.com)

Iverson, R.D., 1996. Employee acceptance of organizational change: the role of organizational commitment. The International Journal of Human Resource Management 7 (1), 122-149. 
Jackson, P.R., 2004. Employee commitment to quality. International Journal of Quality and Reliability Management 21 (7), 714-730.

Karlsson, C., Ahlström, P., 1996. Assessing changes towards lean production. International Journal of Operations and Production Management 16 (2), 24-41.

Koenigsaecker, G., 2005. Leadership and the Lean Transformation. Manufacturing Engineering 135 (5), L7-L11.

Kotter, J.P., 1995. Leading change. Harvard Business Review 73 (2), 59-67.

Landsbergis, P.A., Cahill, J., Schnall, P., 1999. The impact of lean production and related new systems of work organization on worker health. Journal of Occupational Health Psychology 4 (2), 108-130.

Lee, K.S., Gao, T., 2005. Studying Organizational Commitment with the OCQ in Korean Retail Context: Its Dimensionality and Relationships with Satisfaction and Work Outcomes. International Review of Retail, Distribution and Consumer Research 15 (4), 375-399.

Linstead, S., Brewis, J., Linstead, A., 2005. Gender in change: gendering change. Journal of Organizational Change Management 18 (6), 542-560.

LEI, 2004. LEI's First Annual State of Lean Report Defects Solid Gains and Common Obstacles. [online] www.lean.org/WhoWeAre/NewsArticleDocuments/LEI\%20State\%20of\%20 Lean\%20Report\%202\%2004.doc, (accessed 15 ${ }^{\text {th }}$ April 2006).

Macduffie, J.P., 1995. Human resource and manufacturing performance: organizational logic and flexible production systems in the world auto industry. Industrial and Labor Relations Review 48 (2), 197-221.

Matsui, Y., 2007. An emiprical analysis of just-in-time production in Japanese manufacturing companies. International Journal of Production Economics 108 (1-2), 153-164.

McCutcheon, D.M., Meredith, J.R., 1993. Conducting case study research in Operations Management. Journal of Operations Management 11 (3), 239-256.

Medgyesi, M., Róbert, P., 1998. A munka attitüdök időbeli változása 1989-1997 között. TÁRKI Társadalompolitikai Tanulmányok 4., TÁRKI.

Mehri, D., 2006. The darker side of lean: An Insider's perspective on the realities of the Toyota Production System. Academy of Management Perspectives 20 (2), 21-42.

Mowday, R.T., Steers, R.M., Porter, L.W., 1982. Employee-organizational linkages: The psychology of commitment, absenteeism, and turnover. Academic Press, New York.

Neil, C.C., Snizek, W.E., 1987. Work values, job characteristics, and gender. Sociological Perspective 30 (3), 245-265. 
Newsome, K., 2003. The Women Can Be Moved to Fill in the Gaps: New Production Concepts, Gender and Suppliers. Gender, Work, Organization 10 (3), 320-341.

Ng, T.W.H., Butts, M.M, Vandenberg, R.J., DeJoy, D.M., Wilson, M.G., 2006. Effects of management communication, opportunity for learning, and work schedule flexibility on organizational commitment. Journal of Vocational Behaviour 68 (3), 474-489.

Nijhof, W.J., de Jong, M.J., Beukhof, G., 1998. Employee commitment in changing organizations: an exploration. Journal of European Industrial Training 22 (6), 243-248.

Ohno, T., 1988. Toyota Production System - Beyond Large-Scale Production. Productivity Press, Portland, Oregon.

Olorunniwo, F., Udo, G., 2002. The impact of management and employees on cellular manufacturing implementation. International Journal of Production Economics 76 (1) 27-38.

Panizzolo, R., 1998. Applying the lessons learned from 27 lean manufacturers. The relevance of relationships management. International Journal of Production Economics 55 (3), 223-240.

Patterson, M.G., West, M.A., Wall, T.D., 2004. Integrated manufacturing, empowerment, and company performance. Journal of Organizational Behavior 25 (5), 641-665.

Quinn, M.D., 2001. Factors Influencing Employee Commitment to Organizational Change: Moving Toward an Inclusionary Environment. A dissertation submitted in partial fulfillment of the requirements for the degree of doctor of sciences in management system. University of New Haven, West Haven, Connecticut.

Rungtusanatham, M., Forza, C., Filippini, R., Anderson, J.C., 1998. A replication study of a theory of quality management underlying the Deming management method: insights from an Italian context. Journal of Operations Management 17 (1), 77-95.

Shadur, M.A., Rodwell, J.J., Bamber, G.J., 1995. Factors Predicting Employees’ Approval of Lean Production. Human Relations 48 (12), 1403-1424.

Shadur, M. A., Kienzle, R., Rodwell, J. J., 1999. The relationship between organizational climate and employee perceptions of involvement. Group \& Organization Management 24 (4), 479-503.

Shafer, S.M., Tepper, B.J., Meredith, J.R., Marsh, R., 1995. Comparing the effects of cellular and functional manufacturing on employee' perceptions and attitudes. Journal of Operations Management 12 (2), 63-74.

Shah, R., Ward, P.T., 2007. Defining and developing measures of lean production. Journal of Operations Management 25 (4), 785-805.

Singh, P., Finn, D., Goulet, L., 2004. Gender and job attitudes: a re-examination and extension. Women in Management Review 19 (7), 345-355.

Skorstad, E., 1994. Lean Production, Conditions of Work and Worker Commitment. Economic and Industrial Democracy 15 (3), 429-455. 
Spear, S., Bowen, H.K., 1999. Decoding the DNA of the Toyota Production System. Harvard Business Review 77 (5), 96-106.

Taylor, B., 2006. A feminist critique of Japanisation: employment and work in consumer electronics. Gender, Work and Organization 13 (4), 317-337.

Tracy, M. W., 2004. Lean Transformation Questionnaire. [online] http://www.oakland.edu/lean/ download/LeanMfgSurvey forEmployees.pdf\#search=\%22lean\%20questionnaire\%22., (accessed 10 ${ }^{\text {th }}$ June 2006).

Tracy, M.W., Flinchbaugh J.W., 2006. How Human Resource Departments Can Help Lean Transformation. Target 22 (3), 5-10.

Udo, J.G., Ehie I.C., 1996. Advanced Manufacturing Technologies: Determinants of Implementation Success. International Journal of Operations and Production Management 16 (12), 6-26.

Vasilash, G., 2000. How Toyota does it every day. Automotive Manufacturing and Production, August 2000, 48-49.

Venables, M., 2005. Going for Lean. Manufacturing Engineer 84 (4), 26-31

Warnecke, H.J., Huser, M., 1995. Lean production. International Journal of Production Economics 41 (1-3), 37-43.

Womack, J.P., Jones, D.T., 2003. Lean thinking. Banish waste and create wealth in your corporation. Simon \& Schuster UK Ltd, London.

Womack, J.P., Jones, D.T., Roos, D., 1990. The Machine that Changed the World. Rawson Associates, New York.

Yauch, C.A., Steudel, H.J., 2002. Cellular manufacturing for small businesses: key cultural factors that impact the conversion process. Journal of Operations Management 20 (5), 593617.

Zairi, M., 2002. Total quality management sustainability: what it means and how to make it viable. International Journal of Quality and Reliability Management 19 (5), 502-507. 